\title{
HUBUNGAN PEMAHAMAN KONSEP DENGAN KETERAMPILAN BERPIKIR KRITIS MELALUI MODEL PEMBELAJARAN TREFFINGER PADA MATA KULIAH FISIKA DASAR
}

\author{
Fathiah Alatas \\ Pendidikan Fisika UIN Syarif Hidayatullah Jakarta, fathiahalatas@gmail.com
}

\begin{abstract}
Another alternative method to facilitated student to achieve understanding and critical thinking skill are to applied a learning method called Treffinger. This research held for the purpose to understand the relationship between understanding the concept and critical thinking skill on student with the Treffinger learning model. This research held on FITK UIN Syarif Hidayatullah majoring natural science education, between September-November 2012. The design for this research uses one shot case study. The research done in several stages including preparation stage, implementation stage, and data analysis stage. The result of using the Treffinger learning model on teaching subject fluida statist based on the teaching activity of the lecturer on every class occasion are classified as good result. The student activity consider on very good category. The understanding concept of the student that uses the treffinger learning model on teaching subject fluida statis result on average test show 6,35 are in middle category. The student critical thinking skill that uses the treffinger learning model on teaching subject fluida statis result on average test show 6,57 are in middle category. The result of this research on the relation between understanding concept and critical thinking skill uses Treffinger learning model show a significant correlation with middle category of correlation.
\end{abstract}

Keywords: understanding concept, critical thinking skill, Treffinger

\begin{abstract}
Abstrak
Salah satu model alternatif untuk memfasilitasi mahasiswa mencapai pemahaman dan keterampilan berpikir kritis yakni menerapkan model pembelajaran Treffinger. Penelitian ini bertujuan untuk mengetahui hubungan pemahaman konsep dengan keterampilan berpikir kritis mahasiswa melalui model pembelajaran Treffinger. Penelitian ini dilaksanakan di Jurusan Pendidikan IPA FITK UIN Syarif Hidayatullah Jakarta, mulai bulan September-November 2012.Desain yang digunakan dalam penelitian ini adalah one shot case study. Penelitian dilakukan melalui tahap persiapan, pelaksanaan dan analisis data. Hasil penelitian keterlaksanaan model pembelajaran Treffinger materi pokok fluida statis dilihat berdasarkan aktivitas dosen selama proses pembelajaran. Aktivitas dosen dan keterlaksanaan pembelajaran pada setiap pertemuannya kategori sangat baik. Aktivitas mahasiswa termasuk dalam kategori sangat baik. Pemahaman konsep mahasiswa melalui model pembelajaran Treffinger pada sub materi pokok fluida statis dilihat dari nilai rata-rata tes hasil belajar yaitu sebesar 6,35 berada pada kategori cukup. Keterampilan berpikir kritis mahasiswa melalui model pembelajaran Treffinger pada sub materi pokok fluida statis dilihat dari nilai rata-rata tes keterampilan berpikir kritis yaitu sebesar 6,57 berada pada kategori cukup. Terdapat hubungan pemahaman konsep dengan keterampilan berpikir kritis mahasiswa melalui model pembelajaran Treffinger pada sub materi pokok fluida statis berdasarkan hasil perhitungan koefisien korelasi menunjukan hubungan signifikan dengan kategori korelasi sedang.
\end{abstract}

Kata Kunci: pemahaman konsep, keterampilan berpikir kritis, treffinger

\section{PENDAHULUAN}

Salah satu tujuan pendidikan adalah memfasilitasi mahasiswa mencapai pemahaman yang dapat diungkapkan secara lisan, berupa angka, dan kerangka berpikir yang positif (Gardner, 1999a). Pemahaman dapat diabstraksikan sebagai landasan untuk memperoleh kemampuan pemecahan masalah, berpikir kreatif dan kritis, dan pengambilan keputusan (Berns \& Erickson, 2001). Oleh karena itu, pembelajaran untuk pemahaman merupakan pembelajaran untuk berpikir tingkat tinggi.

Pemahaman konsep adalah proses perbuatan untuk mengerti benar tentang suatu rancangan atau suatu ide abstrak yang memungkinkan seseorang untuk menggolongkan suatu objek atau kejadian, dan pemahaman konsep diperoleh melalui proses belajar.

Pemahaman merupakan hasil belajar mengajar yang mempunyai indikator dan setiap individu dapat menjelaskan atau mendefinisikan 
suatu bagian informasi dengan kata-kata sendiri. Dalam taksonomi Bloom, kesanggupan memahami setingkat lebih tinggi daripada mengingat. Pemahaman menurut Sudjana (1990) dapat dibedakan kedalam tiga kategori, yaitu: 1) Pemahaman menerjemahkan berkaitan dengan memahami makna yang sebenarnya. Kata-kata operasional yang digunakan untuk mengukur pemahaman ini antara lain: menyebutkan, mendefinisikan, menunjukan, menerjemahkan, mengubah, dan mengilustrasikan; 2) Pemahaman menafsirkan berkaitan dengan memahami grafik, menghubungkan dua konsep yang berbeda, membedakan yang pokok dan yang tidak pokok. Kata-kata operasional untuk pemahaman ini antara lain: membedakan, menjelaskan, menghitung, menafsirkan, dan lain-lain.

Pemahaman ekstrapolasi merupakan kemampuan melihat di balik yang tertulis atau tersirat dan tersurat, meramalkan sesuatu, memperluas wawasan. Kata-kata operasional untuk pemahaman ini antara lain: memberikan contoh, memperkirakan, menentukan, membuat rangkuman, menarik kesimpulan, meramalkan, dan lain-lain.

Alasan tersebut menekankan pula pentingnya dosen melakukan perubahan paradigma dalam memfasilitasi mahasiswa, dari cara pandang mengajar adalah bercerita tentang konsep menjadi sebuah perspektif ilmiah teoretis. Mengajar adalah mengubah lingkungan belajar dan menyiapkan rangsangan-rangsangan kepada mahasiswa untuk melakukan inquiry learning dan menyelesaikan masalah. (Wenning \& Wenning, 2006). Mengajar bukan berfokus pada how to teach tetapi hendaknya lebih berorientasi pada how to stimulate learning (Wenning, 2006) dan learning how to learn (Novak \& Gowin, 1985).

Pembelajaran untuk pemahaman merupakan pembelajaran untuk berpikir tingkat tinggi, dan salah satu keterampilan berpikir yang harus dimiliki oleh mahasiswa adalah keterampilan berpikir kritis. Salah satu kecakapan hidup (life skill) yang perlu dikembangkan melalui proses pendidikan adalah keterampilan berpikir (Depdiknas, 2003). Keterampilan berpikir dapat didefinisikan sebagai proses kognitif yang dipecah-pecah ke dalam langkah-langkah nyata yang kemudian digunakan sebagai pedoman untuk berpikir (Suprapto, 2008).

Berdasarkan observasi di lapangan, hampir sebagian besar mahasiswa yang mempelajari mata kuliah fisika dasar kurang memahami konsep, akibatnya keterampilan berpikir kritis mereka juga kurang. Aktivitas pembelajaran hanya mengacu pada pembelajaran langsung atau konvensional. Eksperimen dilakukan sebagai bagian dari ketentuan program studi dasar pembelajaran berbasis sains. Akibatnya, eksperimen hanya sebagai syarat, mahasiswa hanya menerima informasi, karena dosen, hanya bercerita tentang konsep. Mahasiswa tidak dibiarkan mencari sendiri pengetahuannya. Mahasiswa mungkin memahami konsep yang disampaikan oleh dosen tetapi mahasiswa kurang memiliki kemampuan berpikir kritis, karena mereka tidak mencari pengetahuannya sendiri. Keterampilan berpikir dapat didefinisikan sebagai proses kognitif yang dipecah-pecah ke dalam langkah-langkah nyata yang kemudian digunakan sebagai pedoman untuk berpikir (Suprapto, 2008).

Kemampuan mahasiswa untuk dapat berhasil dalam pembelajaran antara lain banyak ditentukan oleh keterampilan berpikir yang dimilikinya. Hal utama kemampuan dalam upaya memecahkan masalah-masalah selama mengalami proses pembelajaran. Melalui keterampilan berpikir, mahasiswa dapat melatih dan mengembangkan kecerdasan kognitif yang dimilikinya, serta mampu menghubungkan berbagai fakta atau informasi dengan pengetahuan yang telah dimiliki untuk membuat suatu prediksi hasil akhir yang terumuskan.

Mahasiswa yang kritis dalam pembelajaran fisika dapat belajar bagaimana melihat gejala sadar pembiasaan dirinya, dan mendekati situasi secara objektif serta logis. Sedangkan, berpikir kreatif merupakan kemampuan untuk membentuk kombinasi gagasan-gagasan baru untuk memenuhi kebutuhan (Koes, 2003). Oleh karena itu, agar mahasiswa dapat menjadi sosok yang kreatif, serta sanggup memecahkan masalah-masalah Fisika baik dalam pembelajaran di kampus maupun dalam kehidupan sehari-hari, maka mahasiswa mutlak harus dibekali dengan keterampilan berpikir termasuk didalamnya yaitu keterampilan dalam berpikir kritis.

Keterampilan berpikir kritis dapat membawa mahasiswa untuk bisa melihat sebuah masalah dengan sudut pandang yang berbeda, dimana kemampuan berpikir tersebut menuntun mahasiswa untuk bisa menganalisis sebuah fenomena yang terjadi dengan melihat kekuatan dan kelemahan dari keadaan yang ada. Kemampuan berpikir kritis dapat menuntun mahasiswa untuk terus belajar dari setiap hal yang terjadi. 
Berpikir kritis adalah aktivitas terampil, yang bisa dilakukan dengan lebih baik atau sebaliknya, dan pemikiran kritis yang baik akan memenuhi beragam standar intelektual, seperti kejelasan, relevansi, kecukupan, koherensi, dan lain-lain (Fisher, 2009). Keterampilan berpikir kritis juga dapat dipandang sebagai salah satu modal dasar atau modal intelektual yang sangat penting bagi setiap orang. Oleh karena itu, pengembangan keterampilan berpikir kritis dalam dunia pembelajaran khususnya fisika menjadi sangat penting untuk dikembangkan di sekolah-sekolah pada setiap jenjang pendidikan.

Dengan memiliki keterampilan berpikir kritis ini, mahasiswa akan memiliki keberanian untuk mengungkapkan ide-ide, selalu mempunyai rasa ingin tahu, fleksibel, berpikiran terbuka, jujur, hatihati dalam membuat judgment, berpikiran jernih, teratur dan runut dalam memecahkan suatu masalah, serta pantang menyerah dalam mencari hasil yang optimal.

Berdasarkan penjelasan tersebut, dapat disimpulkan bahwa berpikir kritis sebenarnya meliputi pemeriksaan struktur atau unsur pemikiran yang implisit dalam semua proses penalaran baik tujuan, persoalan, asumsi, konsep, pengujian, pembuktian empirikal, nalar, implikasi, juga penolakan dari titik alternatif dan kerangka acuan tertentu.

Hasil penelitian yang telah dilakukan oleh Nurlita (2008) menunjukan, bahwa penggunaan perangkat pembelajaran berdasarkan masalah berpengaruh terhadap pemahaman dan kemampuan berpikir kritis. Melihat perkembangan zaman, mahasiswa perlu dibekali dengan kemampuan untuk mengkaji setiap masalah secara kritis, sebagaimana Wahab (1990) mengemukakan, bahwa ada empat alasan mengapa mahasiswa perlu dibiasakan mengembangkan kemampuan berpikir kritis, yaitu 1) Tuntutan zaman, kehidupan kita dewasa ini menuntut setiap warga negara dapat mencari, memilih dan menggunakan informasi untuk kehidupan dalam masyarakat dan bernegara; 2) Setiap warganegara senantiasa berhadapan dengan berbagai masalah dan pilihan sehingga dituntut mampu berpikir kritis dan kreatif; 3) Kemampuan memandang sesuatu hal dengan cara baru dalam memecahkan masalah; 4) Aspek dalam memecahkan permasalahan secara kreatif agar mahasiswa kita disatu pihak bisa bersaing dengan fair, dilain pihak bisa bekerjasama dengan bangsabangsa lain.
Mahasiswa perlu dibantu untuk kritis terhadap bahan perkuliahan dan masalah yang dihadapi. Keterampilan berpikir merupakan keterampilan yang sangat penting dimiliki oleh mahasiswa. Dengan keterampilan ini diharapkan mahasiswa mempunyai terbaik dalam menyelesaikan masalah dengan menggunakan berbagai pengetahuan ataupun teori yang telah dipelajari, baik masalah yang bersifat intrapersonal maupun interpersonal. Meningkatkan dan mengembangkan kemampuan berpikir kritis itu tidak bisa hanya diceramahkan atau dijelaskan saja, tetapi harus banyak melatih dan mempraktekkan keterampilan itu. Berdasar pada hal tersebut, maka harus dilakukan suatu upaya untuk membiasakan mahasiswa menganalisis dan mencari upaya pemecahan masalah disekitarnya, salah satunya dengan menggunakan model Treffinger.

Menurut Treffinger (2002) model pembelajaran ini terdiri dari tiga komponen yaitu understanding challenge (memahami tantangan), generating ideas (membangkitkan gagasan-gagasan atau ide-ide) dan preparing for action (mempersiapkan tindakan) yang dirinci ke dalam enam tahapan yaitu tahap menentukan tujuan, menggali data, merumuskan masalah, membangkitkan gagasan, mengembangkan solusi, dan tahap membangun penerimaan.

Tahap pertama dalam model Treffinger adalah menentukan tujuan, mahasiswa mengetahui tujuan pembelajaran yang akan dicapai serta mengetahui manfaat dari teori atau materi yang akan diajarkan. Hal ini membantu memfokuskan perhatian dan energi pada arah dan tujuan yang positif yang membantu menggerakan mahasiswa dengan yakin dan antusias. Kedua menggali data, merupakan tahap mendaftar semua fakta yang diketahui mengenai masalah yang ingin dipecahkan dan menemukan data baru yang diperlukan. Dalam tahap ini kita ingin memperoleh gambaran yang lebih terperinci dan jelas tentang bahasan yang dibicarakan. Ketiga merumuskan masalah, merupakan tahap dimana individu merumuskan masalah melalui pertanyaan-pertanyaan simplistik tertentu, misalnya "mengapa hal tersebut dapat terjadi?". Dengan demikian, individu dapat mengembangkan masalah dengan mengidentifikasi sub-sub masalah, sehingga masalah dapat dirumuskan kembali. Pada tahap ini disusun sebanyak mungkin pertanyaan kreatif sehubungan dengan masalah yang dihadapi.

Tahap keempat, tahap membangkitkan gagasan, tahap dimana individu berupaya 
mengembangkan gagasan pemecahan masalah sebanyak mungkin. Pada tahap ini teknik-teknik yang digunakan: sumbang saran, penulisan gagasan, dan lain-lain. Seluruh mahasiswa diminta untuk membangkitkan gagasannya untuk menjawab permasalahan yang telah dirumuskan. Tahap kelima, mengembangkan solusi, penggunaan strategi dan perlengkapan yang telah dirancang untuk menganalisis, mengembangkan, dan menyaring kemungkinan, dan untuk mengubahnya ke dalam solusi. Mengembangkan solusi dapat membantu untuk menggunakan perlengkapan praktis untuk merubah "gagasan bagus" menjadi solusi baru yang kuat. Misalnya dengan mahasiswa melakukan percobaan untuk memperkuat gagasan yang diambil dengan menggunakan prosedur kerja yang dibuat sendiri oleh mahasiswa. Contohnya masing-masing kelompok selanjutnya diberi seperangkat alat percobaan dengan bahan yang sedikit berbeda, kemudian melakukan percobaan ulang dengan prosedur percobaan seperti yang telah didemonstrasikan.

Tahap keenam yakni tahap membangun penerimaan, dilakukan penyusunan rencana tindakan agar pihak yang mengambil keputusan dapat menerima gagasan tersebut dan melaksanakannya. Merancang untuk membangun dukungan dan untuk mengurangi atau mengatasi hambatan kemungkinan solusi, dan merencanakan cara khusus untuk meningkatkan dan mengevaluasi hasil dan keefektifitas solusi yang telah dikembangkan. Dari pembahasan tersebut, peneliti ingin melakukan penelitian dengan menggunakan model pembelajaran Treffinger untuk mempelajari secara mendalam bahwa model tersebut berpengaruh terhadap pemahaman dan kemampuan berpikir kritis mahasiswa.

Berdasarkan uraian di atas, diduga bahwa terdapat hubungan pemahaman konsep dengan keterampilan berpikir kritis mahasiswa. Untuk itu penelitian ini perlu dilakukan untuk melihat bagaimana keterlaksanaan model pembelajaran Treffinger pada mata kuliah fisika dasar, bagaimana pemahaman konsep mahasiswa melalui model pembelajaran Treffinger pada mata kuliah fisika dasar, bagaimana keterampilan berpikir kritis mahasiswa melalui model pembelajaran Treffinger, serta apakah ada hubungan pemahaman konsep dengan keterampilan berpikir kritis mahasiswa melalui model pembelajaran Treffinger pada mata kuliah fisika dasar.

Pada penelitian ini konsep yang diteliti adalah fluida statis. Konsep ini merupakan konsep yang sangat berkaitan dengan kehidupan seharihari, sehingga banyak pengalaman yang diperoleh mahasiswa sebelum pembelajaran dilaksanakan. Namun pada kenyataannya tidak sedikit mahasiswa mengalami kesulitan dalam mempelajari konsepkonsep fluida statis dan mengaplikasikan dalam permasalahan sehari-hari. Tes pemahaman konsep mahasiswa didasarkan pada indikator-indikator yaitu menafsirkan, mencontohkan, menjelaskan, mengklasifikasikan, merangkum, menyimpulkan, membandingkan (Anderson \& Krathwohl, 2010). Tes keterampilan berpikir kritis mahasiswa didasarkan pada 5 aspek yaitu : memberikan penjelasan sederhana (elementary clarification), membangun keterampilan dasar (basic support), menyimpulkan (inference), membuat penjelasan lebih lanjut (advanced clarification), strategi dan taktik (strategies and tactics).

\section{METODE PENELITIAN}

Desain penelitian yang dijadikan kerangka acuan dalam melakukan penelitian ini adalah one shot case study. Penelitian ini mengambil lokasi penelitian di Jurusan Pendidikan IPA Fakultas Tarbiyah dan Ilmu Keguruan (FITK) UIN Syarif Hidayatullah. Populasi dalam penelitian ini adalah seluruh mahasiswa yang mengambil mata kuliah fisika dasar I. Sampel dalam penelitian diambil 1 kelas yaitu mahasiswa yang mengambil mata kuliah fisika sasar di program studi Fisika. Pengambilan sampel dilakukan dengan mengunakan teknik cluster sampling (Sugiyono, 2009).

\section{Teknik Pengumpulan Data}

Jenis data yang diambil dalam penelitian ini adalah data kuantitatif dan kualitatif. Data yang diperoleh dalam penelitian ini berupa data kualitatif dan kuantitatif.

Data kualitatif berupa data yang tidak berbentuk angka (Subana, 2000). Data kualitatif ini diperoleh dari lembar observasi aktivitas dosen dan mahasiswa, berupa pedoman lembar observasi aktivitas dosen dan mahasiswa ini bertujuan untuk mengetahui keterlaksanaan model pembelajaran Treffinger. Indikator pengamatan aktivitas dosen dan mahasiswa meliputi tahapan yang ada pada model pembelajaran Treffinger. Instrumen observasi berbentuk rating scale berupa pilihan ya dan tidak. Indikator pengamatan aktivitas dosen dan mahasiswa meliputi tahapan yang ada pada model pembelajaran Treffinger.

Data kuantitatif, berupa data yang berbentuk bilangan atau angka (Subana, 2000). Data kuantitatif diperoleh dari tes pemahaman konsep dan 
keterampilan berpikir kritis. Tes yang diberikan berupa essai. Sebelum digunakan sebagai instrumen penelitian, instrumen ini diuji kelayakan terlebih dahulu secara kualitatif. Uji kelayakan ini berupa judgment kepada dosen ahli untuk mengetahui ketepatan penggunaan dalam penelitian yang didalamnya meliputi konstruksi, bahasa dan materi instrumen terkait.

\section{Teknik Data}

Data yang diperoleh seluruhnya dianalisis sebagai berikut:

Analisis data hasil observasi, berupa data mengenai aktivitas dosen dan mahasiswa pada saat melakukan kegiatan belajar mengajar dengan menggunakan model pembelajaran Treffinger diolah dengan presentase.Analisis data hasil tes pemahaman konsep dan tes keterampilan berpikir kritis merupakan pengolahan data dari skor tes hasil belajar mahasiswa.

Tes yang digunakan dalam penelitian ini adalah tes pemahamankonsep dan tes keterampilan berpikir kritis yang telah diuji cobakan dengan tujuan untuk mengetahui kelayakan instrumen tersebut. Tes Pemahaman konsep, diberikan berupa essai dengan jumlah 12 soal sesuai dengan indikator pembelajaran dan pemahaman konsep. Tes keterampilan berpikir kritis yang diberikan berupa essai dengan jumlah 12 soal yang disesuaikan dengan indikator keterampilan berpikir kritis. Sebelum digunakan sebagai instrumen penelitian, tes ini diuji kelayakan terlebih dahulu secara kualitatif dan kuantitatif. Uji kelayakan kualitatif berupa judgment kepada dosen ahli untuk mengetahui ketepatan penggunaan dalam penelitian yang didalamnya meliputi konstruksi, bahasa dan materi instrumen terkait.

Analisis hubungan pemahaman konsep dengan keterampilan berpikir kritis, berupa hasil analisis data dari tes pemahaman konsep dengan tes keterampilan berpikir kritis digunakan untuk menjawab rumusan masalah mengenai hubungan keterampilan berpikir kritis (variabel $\mathrm{X}$ ) dengan hasil belajar (variabel Y). Selain itu,hubungan pemahaman konsep dengan tes keterampilan berpikir kritis ini juga merupakan hipotesis yang penulis ajukan dalam penelitian. Pengujian hipotesis menggunakan persamaan korelasi dengan program SPSS.

\section{HASIL DAN PEMBAHASAN}

\section{Keterlaksanaan Pembelajaran Fisika}

Penelitian yang dilakukan di Jurusan Pendidikan IPA mengambil mata kuliah Fisika Dasar I dengan menggunakan model pembelajaran Treffinger. Pembelajaran dilakukan selama tiga kali pertemuan dan 2 kali tes hasil belajar yang dimulai tanggal 11 Oktober 2012 sampai 08 November 2012. Observasi dilakukan selama pelaksanaan pembelajaran. Hal ini dilakukan dengan memperhatikan pedoman observasi kegiatan pembelajaran yang telah disiapkan dan untuk memperoleh gambaran mengenai penerapan model pembelajaran Treffinger, serta sesuai tidaknya langkah pembelajaran yang dilakukan peneliti sebagai dosen dengan langkah-langkah model pembelajaran Treffinger. Interpretasi keterlaksanaan aktivitas dosen dan mahasiswa setiap pertemuan dapat di lihat pada Tabel 1 .

Tabel 1 Rata-rata Keterlaksanaan Aktivitas Dosen Tiap Pertemuan

\begin{tabular}{ccccc}
\hline No. & Pembelajaran & \multicolumn{2}{c}{ Skor rata-rata (\%) } & Kete- \\
& & Terlaksana & $\begin{array}{c}\text { Tidak } \\
\text { terlaksana }\end{array}$ & \\
\hline $\mathbf{1}$ & Pertemuan & 100 & 0 & $\begin{array}{c}\text { Sangat } \\
\text { ke-1 }\end{array}$ \\
\cline { 3 - 4 } $\mathbf{2}$ & $\begin{array}{c}\text { Pertemuaik } \\
\text { ke-2 }\end{array}$ & 100 & 0 & $\begin{array}{c}\text { Sangat } \\
\text { Baik }\end{array}$ \\
$\mathbf{3}$ & $\begin{array}{c}\text { Pertemuan } \\
\text { ke-3 }\end{array}$ & 100 & 0 & $\begin{array}{c}\text { Sangat } \\
\text { Baik }\end{array}$ \\
& Rata-rata & 100 & 0 & $\begin{array}{c}\text { Sangat } \\
\text { Baik }\end{array}$ \\
\hline
\end{tabular}

Berdasarkan Tabel 1, keterlaksanaan proses pembelajaran dengan menggunakan model pembelajaran Treffinger dapat disimpulkan bahwa proses keterlaksanaan termasuk kategori sangat baik yaitu sebesar $100 \%$. Pada pertemuan pertama persentase keterlaksanaan pembelajaran sebesar $100 \%$. Namun demikian meski sudah direncanakan dengan maksimal, dosen kurang dalam mengelolaan kelas, sehingga tidak semua mahasiswa dapat memperhatikan tiap fase pembelajaran dengan baik. Untuk keterlaksanaannya dosen termasuk kategori sangat baik dalam melaksanakan pembelajaran.

Pada pertemuan kedua dan ketiga, dosen dapat memaksimalkan keterlaksanaan pada setiap tahap pembelajaran dengan menggunakan model pembelajaran Treffinger. Dosen mampu mengelola waktu dengan baik, sehingga tahap-tahap pembelajaran yang direncanakan sesuai Satuan Acara Perkuliahan (SAP) dapat diselesaikan dengan baik pula. Dosen mampu membimbing dan 
mengarahkan mahasiswa pada saat diskusi kelompok sehingga mahasiswa mulai berani untuk bertanya, menanggapi dan berbagi ide dengan teman sekelompoknya. Dosen juga mampu membimbing mahasiswa untuk melaksanakan presentasi yang komunikatif. Secara keseluruhan, berdasarkan hasil analisis observasi aktivitas dosen selalu tetap dengan presentase maksimal, tetapi berdasarkan keterlaksanaan observer di luar tahapan pembelajaran misalnya ketepatan waktu dan sebagainya, pembelajaran dari pertemuan pertama sampai dengan pertemuan terakhir mengalami peningkatan. Hasil rata-rata analisis observasi aktivitas mahasiswa pada pembelajaran pertemuan kesatu, kedua, dan ketiga selama pembelajaran disajikan pada pada Tabel 2.

Tabel 2. Rata-rata Keterlaksanaan Aktivitas Mahasiswa

\begin{tabular}{rlccl}
\hline & $\begin{array}{l}\text { Pembelaja- } \\
\text { Non }\end{array}$ & Skor rata-rata $(\%)$ & $\begin{array}{l}\text { Keterang- } \\
\text { an }\end{array}$ \\
\cline { 2 - 4 } & Terlaksana & $\begin{array}{c}\text { Tidak } \\
\text { Terlaksana }\end{array}$ & \\
\hline $\mathbf{1}$ & $\begin{array}{l}\text { Pertemuan } \\
\text { ke-1 }\end{array}$ & 100 & 0 & $\begin{array}{l}\text { Sangat } \\
\text { Baik }\end{array}$ \\
$\mathbf{2}$ & $\begin{array}{l}\text { Pertemuan } \\
\text { ke-2 }\end{array}$ & 95 & 5 & $\begin{array}{l}\text { Baik } \\
\mathbf{3}\end{array}$ \\
$\begin{array}{l}\text { Pertemuan } \\
\text { ke-3 }\end{array}$ & 100 & 0 & $\begin{array}{l}\text { Sangat } \\
\text { Baik }\end{array}$ \\
\hline Rata-rata & 98.3 & 1.7 & $\begin{array}{l}\text { Sangat } \\
\text { Baik }\end{array}$ \\
\hline
\end{tabular}

Berdasarkan Tabel 2, keterlaksanaan aktivitas rata-rata mahasiswa selama proses pembelajaran termasuk kategori sangat baik yaitu sebesar 98.3\%. Pada pertemuan pertama keterlaksanaan pembelajaran mencapai $100 \%$. Mahasiswa dapat memperhatikan arahan juga menuruti bimbingan yang disampaikan oleh dosen. Tetapi pada saat dosen memberikan pertanyaan untuk memotivasi, hanya satu mahasiswa yang menanggapi, dan pada saat diskusi kelompok, hanya sedikit mahasiswa yang menanggapi.

Pada pertemuan ke-2 terjadi penurunan sehingga keterlaksanaan pembelajaran mencapai 95\%. Pada pertemuan ke-3 keterlaksanaan pembelajaran menggunakan model pembelajaran Treffinger dilaksanakan dengan baik mencapai $100 \%$, Mahasiswa dapat memperhatikan arahan juga menuruti bimbingan yang disampaikan oleh dosen. Pada saat diskusi kelompok, mahasiswa mulai berani untuk bertanya, menanggapi dan berbagi ide dengan teman sekelompoknya. Bahkan mahasiswa terbiasa menjawab pertanyaan dengan menggunakan persamaan-persamaan sesuai materi yang dipelajari. Mahasiswa juga melaksanakan percobaan dengan baik melalui kerjasama yang kompak.

\section{Analisis Data}

Berdasarkan hasil tes belajar, pemahaman konsep mahasiswa melalui model pembelajaran Treffinger pada sub materi pokok fluida statis dilihat dari nilai rata-rata tes hasil belajar yaitu sebesar 6,35 berada pada kategori cukup. Keterampilan berpikir kritis siswa melalui model pembelajaran Treffinger pada materi pokok fluida statis dilihat dari nilai rata-rata tes keterampilan berpikir kritis yaitu sebesar 6,57 berada pada kategori cukup.

Selanjutnya diperoleh analisis data korelasi yang sebelumnya dihitung normalitas dan regresi linear, baru dihitung korelasinya. Berdasarkan perhitungan SPSS diperoleh analisis data sebagai berikut:

Uji Normalitas, menggunakan uji KolmogorovSmirnov diperoleh data pada Tabel 3. Berdasarkan Tabel 3 terlihat Sig. (2-tailed), data berdistribusi normal jika Asymp. Sig $\alpha=0,05$. Pada Tabel 3 Pemahaman konsep (PK) nilai sig 0,739, dimana nilainya diatas 0,05 maka distribusi data dinyatakan memenuhi asumsi normal. Untuk Keterampilan Berpikir Kritis $(\mathrm{KBK})(\mathrm{Sig}=0,699)$ nilainya lebih besar dari $\alpha=0,05$. Artinya, data berdistribusi normal selanjutnya dilakukan uji korelasi Pearson. Sebelumnya dilakukan uji kelinearan terlebih dahulu.

Tabel 3. Uji Normalitas Data Kolmogorov-Smirnov

\begin{tabular}{llll}
\hline Keterangan & & PK & KBK \\
\hline $\mathbf{N}$ & & 49 & 49 \\
$\begin{array}{l}\text { Parameter } \\
\text { Normal }\end{array}$ & Rata-rata & 6.3753 & 6.5645 \\
& $\begin{array}{l}\text { Standar } \\
\text { Deviasi }\end{array}$ & 1.33375 & 1.41994 \\
& Absolut & 0.098 & 0.101 \\
$\begin{array}{l}\text { Most Extreme } \\
\text { Differences }\end{array}$ & Positif & 0.073 & 0.082 \\
& Negatif & -0.098 & -0.101 \\
& & 0.683 & 0.707 \\
Kolmogorov-Smirnov Z & & \\
& & 0.739 & 0.699 \\
\hline
\end{tabular}


Uji Regresi Linear

Uji ini dilakukan untuk mengetahui apakah satu variabel bergantung pada variabel lain. Diperoleh data pada Tabel 4.

Tabel 4. Ringkasan Model

\begin{tabular}{|c|c|c|c|c|c|}
\hline $\begin{array}{l}\text { Mod } \\
\text {-el }\end{array}$ & $\mathbf{R}$ & $\begin{array}{l}\text { Koefisien } \\
\text { diterminasi } \\
\text { (R Square) }\end{array}$ & $\begin{array}{l}\text { Nilai } \\
\text { koefisien } \\
\text { ditermin- } \\
\text { asi yang } \\
\text { telah } \\
\text { disesuai- } \\
\text { kan }\end{array}$ & $\begin{array}{l}\text { Estimasi } \\
\text { standar } \\
\text { eror }\end{array}$ & $\begin{array}{l}\text { Durb- } \\
\text { in } \\
\text { Wats- } \\
\text { on }\end{array}$ \\
\hline 1 & $\begin{array}{l}0,651 \\
\mathrm{a}\end{array}$ & 0,423 & $\begin{array}{ll} & 0,41 \\
1 & \end{array}$ & $\begin{array}{l}1,0896 \\
1\end{array}$ & 1,531 \\
\hline
\end{tabular}

a. Prediktor: (Konstan), PK

b. Variable Independen: KBK

Kolom R berdasarkan Tabel 4 diperoleh data bernilai 0,651 artinya hubungan kedua variabel penelitian berada pada kategori sedang antara pemahaman konsep mahasiswa dengan keterampilan berpikir kritisnya. Selanjutnya menghitung taraf signifikansi atau kelinieran hubungan antara pemahaman konsep mahasiswa dengan keterampilan berpikir kritis yang disajikan melalui Tabel_6. Kriterianya dapat ditentukan berdasarkan uji F atau uji nilai Signifikansi (Sig.). Cara yang paling mudah dengan uji Sig, dengan ketentuan, jika Nilai Sig. <0.05, maka model regresi adalah linier, dan berlaku sebaliknya.

Tabel 5. ANOVA ${ }^{\mathrm{b}}$

\begin{tabular}{cccccc}
\hline Model & $\begin{array}{c}\text { Jumlah } \\
\text { kuadrat } \\
\text { (Sum of } \\
\text { Squares) }\end{array}$ & Df & $\begin{array}{c}\text { Mean } \\
\text { Square }\end{array}$ & F & Sig. \\
\hline Regresi & 40.978 & 1 & 40.978 & 34.515 & $.000^{\mathrm{a}}$ \\
Residual & 55.801 & 47 & 1.187 & & \\
Total & 96.779 & 48 & & & \\
\hline
\end{tabular}

a. Prediktor: (Konstan), PK

b. Dependent Variable: KBK

Berdasarkan Tabel 5 diperoleh nilai sig $=0.0$ yang berarti lebih kecil dari kriteria signifikan $(0,05)$, dengan demikian model persamaan regresi berdasarkan data penelitian adalah signifikan artinya, model regresi linier memenuhi kriteria linieritas maka terjadi hubungan linier antara pemahaman konsep dengan keterampilan berpikir kritis. Tahap berikutnya adalah menghitung hasil analisis regresi untuk menguji kelinieran korelasi. Persamaan regresi $\mathrm{Y}=\mathrm{a}+\mathrm{bX}$. Maka persamaan regresinya adalah: $\mathrm{Y}=2,418+0,693 \mathrm{X}$

Uji Hipotesis

Langkah terakhir adalah menguji hubungan antara pemahaman konsep dengan keterampilan berpikir kritis. Data dihitung dengan menggunakan Korelasi Pearson karena data berdistribusi normal. Hasil perhitungan disajikan pada Tabel 6. Tolak Ho jika Sig $\alpha=0,05$, karena nilai Sig $=0,000$ dan lebih kecil dari $\alpha=0,05$ artinya ada korelasi antara pemahaman konsep dengan keterampilan berpikir kritis.

Tabel 6. Hasil Uji Korelasi (Correlations) antara Pemahaman Konsep dengan Keterampilan Berpikir

\begin{tabular}{|c|c|c|c|}
\hline & & $\begin{array}{l}\text { Pemahaman } \\
\text { Konsep }\end{array}$ & $\begin{array}{l}\text { Keterampilan } \\
\text { Berfikir Kritis }\end{array}$ \\
\hline \multirow[t]{3}{*}{ PK } & $\begin{array}{l}\text { Korelasi } \\
\text { Pearson }\end{array}$ & 1 & $0,651^{* *}$ \\
\hline & $\begin{array}{l}\text { Sig. } \\
\text { tailed) }\end{array}$ & & .000 \\
\hline & $\mathrm{N}$ & 49 & 49 \\
\hline \multirow[t]{3}{*}{ KBK } & $\begin{array}{l}\text { Korelasi } \\
\text { Pearson }\end{array}$ & $0,651^{* *}$ & 1 \\
\hline & $\begin{array}{l}\text { Sig. } \\
\text { tailed })\end{array}$ & 0,000 & \\
\hline & $\mathrm{N}$ & 49 & 49 \\
\hline \multicolumn{4}{|c|}{ **. Korelasi signifikan pada level 0.01 (2-tailed). } \\
\hline
\end{tabular}

Berdasarkan data pada Tabel 6, nilai koefisien korelasi antara pemahaman konsep dengan keterampilan berpikir kritis adalah 0,651. Berdasarkan hasil uji hipotesis dengan menggunakan Korelasi Pearson karena data berdistribusi normal terdapat hubungan pemahaman konsep dengan keterampilan berpikir kritis mahasiswa melalui model pembelajaran Treffinger pada sub materi pokok fluida statis berdasarkan hasil perhitungan koefisien korelasi menunjukan hubungan signifikan dengan kategori korelasi sedang.

Model pembelajaran ini bisa menjadi pilihan dalam mengembangkan pemahaman dan keterampilan berpikir bagi mahasiswa. Perhatian institusi-institusi pendidikan di negara maju yang tertuju pada pengembangan dan penerapan strategi pembelajaran untuk pemahaman dan keterampilan berpikir tingkat tinggi dapat dipahami dan patut juga dilakukan di institusi pendidikan tinggi di Indonesia. Indonesia juga telah melakukan perbaikan terhadap penyelenggaraan pembelajaran di semua tingkatan institusi pendidikan untuk tujuan peningkatan pemahaman dan keterampilan pemecahan masalah (Puskur, dalam Warpala, 2006) walaupun upaya pencapaian tujuan tersebut belum optimal.

Model pembelajaran yang tepat dan lebih bermakna bagi mahasiswa yaitu model yang berpusat pada keterampilan dalam pemecahan masalah yang menuntut mahasiswa untuk berpikir kritis. Ketika dihadapkan pada suatu permasalahan, 
mahasiswa dapat melakukan keterampilan memecahkan masalah dengan memilih dan mengembangkan ide serta gagasannya. Salah satu model pembelajaran tersebut antara lain adalah model Treffinger.

Hasil Penelitian menunjukkan bahwa kemampuan berpikir kritis dan pemahaman konsep dalam model Treffinger memiliki hubungan yang sedang dengan nilai keterandalan 65,4\%. Model Treffinger memiliki sintaks yang memberdayakan kemampuan berpikir kritis. Berpikir kritis dalam model Treffinger merupakan alat yang digunakan Mahasiswa untuk mengkonstruk pemahamannya.

\section{PENUTUP}

Kesimpulan yang diperoleh dari hubungan pemahaman konsep dan kemampuan berpikir kritis Mahasiswa dengan menerapkan model pembelajaran Treffinger adalah sebagai berikut:

1. Keterlaksanaan model pembelajaran Treffinger sub materi pokok fluida statis dilihat berdasarkan aktivitas dosen selama proses pembelajaran pada setiap pertemuannya hampir dapat terlaksana secara keseluruhan dalam kategori sangat baik. Kemudian aktivitas mahasiswa termasuk dalam kategori sangat baik.

2. Pemahaman konsep mahasiswa melalui model pembelajaran Treffinger pada sub materi pokok fluida statis dilihat dari nilai rata-rata tes hasil belajar yaitu sebesar 6,35 berada pada kategori cukup.

3. Keterampilan berpikir kritis siswa melalui model pembelajaran Treffinger pada sub materi pokok fluida statis dilihat dari nilai rata-rata tes keterampilan berpikir kritis yaitu sebesar 6,57 berada pada kategori cukup.

4. Terdapat hubungan pemahaman konsep dengan keterampilan berpikir kritis Mahasiswa melalui model pembelajaran Treffinger pada sub materi pokok fluida statis berdasarkan hasil perhitungan koefisien korelasi menunjukan hubungan signifikan dengan kategori korelasi sedang.

\section{DAFTAR PUSTAKA}

Anderson, Lorin W. dan Krathwohl, David R. (eds.). 2010. Kerangka Landasan untuk Pembelajaran, Pengajaran, dan Asesmen: Revisi Taksonomi Pendidikan Bloom, terjemahan dari A Taxonomy for Learning,
Teaching, and Assessing: A Revision of Blooms Taxonomy of Educational Objectives oleh Agung Prihantoro, Yogyakarta: Pustaka Pelajar.

Arikunto S. 2010. Prosedur Penelitian Suatu Pendekatan Praktik Edisi Revisi IV. Jakarta: Rineka Cipta.

Berns RG, Erickson PM. 2001. Contextual Teaching and Learning: Preparing Students for the New Economy. Available at http://www.cord.org/ diakses 24 Nopember 2012.

Bloom BS. 1979. Taxonomy of Education Objectives, The Classification Of Education Goals, (Hand Book 1: Cignitive Domain), Usa : Longman Inc.

Depdiknas, 2003, Pedoman Khusus Pengembangan silabus dan Penilaian. Jakarta

Ennis RH. 1996. Critical Thinking. New Jersey: Pretince Hall.

Fisher A. 2009. Berpikir Kritis: Sebuah Pengantar. Jakarta: Erlangga.

Gardner H. 1999. The dicipline mind: What all students should Understand. New York: Simon \& Schuster Inc.

Novak JD, Gowin DB. 1985. Leaning how to learn. New York, NY: Cambridge University Press.

Nurlita F. 2008. Penggunaan Perangkat Pembelajaran Berdasarkan Masalah Untuk Meningkatkan Pemahaman Konsep Dan Mengembangkan Keterampilan Berpikir Kritis. Jurnal Ilmiah Pendidikan dan Pembelajaran, (Online), 4(2): 885-901, (http://isjd.pdii.lipi.go.id), diakses 24 Nopember 2012.

Sudjana N. 1990. Dasar-dasar Proses Belajar. Bandung: Sinar baru Algesindo.

Sugiyono. 2009. Metode Penelitian Kuantitatif, Kualitatif dan $R \& D$. Bandung: Penerbit Alfabeta.

Suprapto. 2008. Menggunakan Keterampilan Berpikir untuk Meningkatkan Mutu Pembelajaran. [online]. Tersedia: http://supraptojielwongsolo.wordpress/cpm. [13 September 2012].

Treffinger, Donald J. 2003. Creative Problem Solving A Contemporary Framework for Managing Change. Orchardd Park: CPSB.@.

Wahab. 1990. Pendidikan PPK. Jakarta: Depdikbud 
Alatas, F.

Warpala IWS. 2006. Pengaruh Pendekatan Pembelajaran dan Strategi Belajar Kooperatif terhadap Pemahaman dan Keterampilan Berpikir Kritis siswa kelas V SD di Kecamatan Kututambahan, Disertasi, Malang: PPS UM-PSSJ TEP, tidak diterbitkan.

Wenning CJ. 2006. A pramework for teaching the nature of science. Journal of Physics Teacher Education Online 3(3):3-10.
Wenning CJ., \& Wenning, R. E. 2006. A generic model for inquiry-oriented lab in postsecondary introductory physics. Journal of Physics Teacher Education Online. 3(3). 24-33. Available http://www.phy.ilstu.edu/jpteo. 
Hubungan Pemahaman Konsep dengan Keterampilan Berpikir Kritis 